\title{
GROWTH, YIELD, WATER USE EFFICIENCY AND COMPETITIVE FUNCTIONS OF INTERCROPPING SYSTEM OF MAIZE (Zea mays L.) AND MUNGBEAN (Vigna radiata L.) AS INFLUENCED BY IRRIGATION
}

\author{
S. Roy ${ }^{1}$, M. Barman ${ }^{1}$, A. M. Puste ${ }^{*^{2}}$, S. K. Gunri ${ }^{2}$ and K. Jana ${ }^{2}$ \\ Department of Agronomy, Bidhan Chandra Krishi Viswavidyalaya, West Bengal, India
}

\begin{abstract}
Field experiment was conducted at Instructional Farm, Jaguli (Mohanpur), Bidhan Chandra Krishi Viswavidyalaya, West Bengal, India during two consecutive summer seasons of 2010-11, and 2011-12. The experiment was laid out in split-plot design having 4 levels of irrigationrainfed without mulch, rainfed with mulch, irrigation at IW (depth of irrigation water) / CPE (Cumulative pan evaporation) ratios of 0.5 and 0.75 in main-plot and 4 inter cropping systems, sole maize, sole mungbean, maize + mungbean (1:1 row ratio) and maize + mungbean (3:2 row ratio) considered as sub-plot treatments replicated thrice. Results revealed that application of irrigation and intercropping systems markedly influenced the growth, yield and yield components (number of cobs/plant, number of grains/cob in case of maize and number of pods/plant and number of seeds/pod in case of mungbean) where the maximum value of these components were recorded with the application of irrigation at IW/CPE ratio 0.75 in sole crop. Maize-mungbean in 3:2 row ratio yielded higher than that of 1:1 intercropping system which might be due to less light interception and more competition for water and nutrition between both the crops. CU of water increased with the increasing levels of irrigation and the maximum value $\left(17.75 \mathrm{~kg} \mathrm{ha}^{-1} \mathrm{~mm}^{-}\right.$ ${ }^{1}$ ) of WUE (water use efficiency) was observed with irrigation at IW: CPE ratio 0.75 under intercropping system of maize : mungbean in 3:2 row ratio followed by IW: CPE ratio 0.50 . Among the sole crop, maximum WUE was with IW/CPE ratio 0.75 might be due to more consumption of water corresponding to production potential of maize, while, it was more under rainfed with mulch in mungbean. The relative crowding coefficient (RCC) also revealed both the intercropping systems were advantageous and the land equivalent ratio (LER) increased with the level of irrigation.
\end{abstract}

\footnotetext{
*Corresponding author email: ampuste bckv@yahoo.co.in

${ }^{1}$ Post Graduate Student, Department of Agronomy, B.C.K.V., Mohanpur - 741 252, West Bengal, India

${ }^{2}$ Associate \& Assistant Professor, Department of Agronomy, B.C.K.V., Mohanpur - 741 252, West Bengal, India
} 
Thus, maize grown in association with mungbean (3:2 row ratio) were found to be more profitable (B:C ratio of 2.58) with higher monetary advantage as compared to sole crop of maize (B:C ratio of 1.98$)$ with the application of irrigation at IW: CPE ratio of 0.75 in new alluvial zone of West Bengal.

Keywords: Intercropping system, maize-mungbean, irrigation, growth, yield, water use efficiency, competitive functions

\section{INTRODUCTION}

Intercropping is considered the best means of stabilizing yield, crop production by increasing the productivity of land and also minimizing the risk of crop failure in dry lands. Many instances of better insect-pest and disease control have also been reported by Mandal et al. (1990) and Banik and Sharma (2009) through intercropping system. In India, agriculture is mainly based on monsoon that is mostly uncertain and unevenly distributed over the sub-continent. So, in such situation, proper scheduling of irrigation maintains the soil moisture at levels up to the crop needs. Maize (Zea mays L.) is one of the most important cereals after rice and wheat that shows great adaptability to wide range of agro-climatic regions and soil types. Among the pulse crops, mungbean (Vigna radiata L.) being leguminous, short duration pre-kharif crop with high quality protein (nearly $25 \%$ ) could be well fitted in various intercropping systems. In view of the above context, this experiment was undertaken with the objectives to study the growth, yield and water use efficiency of maize and mungbean grown as sole and intercrop as influenced by levels of irrigation in this agro-zone.

\section{MATERIALS AND METHODS}

The experiment was conducted during two consecutive pre-kharif or summer seasons of 2010-11 and 2011-12 at Instructional Farm, Jaguli (Mohanpur), Bidhan Chandra Krishi Viswavidyalaya, West Bengal, India in upland situation. The soil of the region was nearly neutral with $\mathrm{pH}$ of 6.45 and sandy loam in texture. Physicochemical properties of the experimental soil up to the depth of $15 \mathrm{~cm}$ were studied to know the initial status before conducting the experiment (Table 1). The soil of experimental field was sandy loam in texture with moderate drainage facilities having medium fertility status and neutral in reaction $(\mathrm{pH}$ 6.45). The important characteristics were medium organic matter and total nitrogen content of $0.059 \%$. The values of available $\mathrm{P}$ and $\mathrm{K}$ were determined $8.71 \mathrm{~kg}$ and $104.9 \mathrm{~kg} \mathrm{ha}{ }^{-1}$, respectively. Besides, bulk densities values of soil at depths $(0-15) \mathrm{cm},(15-30) \mathrm{cm}$, $(30-45) \mathrm{cm}$ and $(45-60) \mathrm{cm}$ were measured $1.45,1.47,1.49$ and $1.52 \mathrm{~g} \mathrm{cc}^{-1}$, respectively.

Cultivars of maize and mungbean used were 'Deccan 105' and 'Sonali', respectively. Field experiment was carried out under irrigated conditions laid out in 
split-plot design with 4 levels of irrigation (main-plot treatments) and 4 cropping systems (sub-plot treatments) replicated thrice. Total number of plots was 48 each of $20 \mathrm{sq} \mathrm{m}$ area $(5 \mathrm{~m} \mathrm{x} 4 \mathrm{~m})$ and irrigation channel was provided of $1.0 \mathrm{~m}$ width including $1.0 \mathrm{~m}$ of buffer channel in between main-plot irrigation treatments avoiding any water transfer by seepage among the adjacent plots.

In main-plot treatments, the levels of irrigation were as follows: $\mathrm{I}_{0}=$ rainfed without mulch, $\mathrm{I}_{1}=$ rainfed with mulch, $\mathrm{I}_{2}=$ irrigation at IW/CPE ratio of 0.5 and $\mathrm{I}_{3}=$ irrigation at IW/CPE ratio of 0.75 and 4 different intercropping systems under subplots were: $\mathrm{C}_{1}$ - sole maize, $\mathrm{C}_{2}$ - sole mungbean, $\mathrm{C}_{3}$ - maize: mungbean maintained at 1:1 row ratio and $\mathrm{C}_{4}$ - maize: mungbean maintained at 3:2 row ratio, respectively.

Growth parameters such as plant height $(\mathrm{cm})$, crop growth rate $\left(\mathrm{CGR}, \mathrm{g} \mathrm{m}^{-2}\right.$ day $\left.^{-1}\right)$, dry matter accumulation $\left(\mathrm{g} \mathrm{m}^{-2}\right)$, leaf area indices (LAI) were recorded. Besides, yield and yield components viz., number of cobs plant ${ }^{-1}$, length of cobs, number of grains $\mathrm{cob}^{-1}$, test weight and grain yield $\left(\mathrm{t} \mathrm{ha}^{-1}\right)$ in case of maize; number of pods plant ${ }^{-1}$, length of pods, number of seeds pod $^{-1}$, test weight and seed yield ( $t$ $\mathrm{ha}^{-1}$ ) in case of mungbean were also recorded Furthermore, consumptive use of water $(\mathrm{mm})$, water use efficiency $\left(\mathrm{kg} \mathrm{ha}^{-1} \mathrm{~mm}^{-1}\right)$ was also analysed using the following equations:

$$
\mathrm{U}=\sum \mathrm{u}=\sum \frac{\mathrm{M} 1_{\mathrm{i}}-\mathrm{M} 2_{\mathrm{i}}}{100} \times \quad \text { BDi } \mathrm{x} \quad \mathrm{Di}
$$

Where, $\mathrm{U}=$ total water use $(\mathrm{mm})$

$\mathrm{u}=$ water use in $\mathrm{mm}$ from the root zone for the periods between successive sampling

$\mathrm{n}=$ number of soil layers sampled in the root zone depth (D)

$\mathrm{M} 1_{\mathrm{i}}=$ Soil moisture percentage at the time of first sampling or after irrigation in the $\mathrm{i}^{\text {th }}$ layer

$\mathrm{M} 2_{\mathrm{i}}=$ Soil moisture percentage at the time of second sampling or before irrigation in the $\mathrm{i}^{\text {th }}$ layer

$\mathrm{BDi}=$ bulk density of the $\mathrm{i}^{\text {th }}$ layer $(\mathrm{g} / \mathrm{cc})$

$\mathrm{Di}=$ depth of $\mathrm{i}^{\text {th }}$ layer of soil $(\mathrm{cm})$

Various competitive functions like aggressivity, land equivalent ratio (LER) and relative crowding coefficient (RCC) were also calculated to find out the yield advantages of the intercropping systems. Aggressivity was calculated using the following formula:

$$
\operatorname{Aggressivity~}\left(\mathrm{A}_{\mathrm{ab}}\right)=\frac{\mathrm{Y}_{\mathrm{ab}}}{\mathrm{Y}_{\mathrm{aa}} \mathrm{XZ}_{\mathrm{ab}}}-\frac{\mathrm{Y}_{\mathrm{ba}}}{\mathrm{Y}_{\mathrm{bb}} \mathrm{X} \mathrm{Z}_{\mathrm{ba}}}
$$


Where, $A_{a b}=$ Aggressivity of species ' $a$ ' in presence of species ' $b$ '

$Y_{a b}=$ Intercrop yield of species ' $a$ ' in presence of species ' $b$ '

$\mathrm{Y}_{\mathrm{aa}}=$ Pure stand yield of species ' $\mathrm{a}$ '

$Y_{b a}=$ Intercrop yield of species ' $b$ ' in presence of species ' $a$ '

$Y_{b b}=$ Pure stand yield of species ' $b$ '

$\mathrm{Z}_{\mathrm{ab}}=$ Sown proportion of species ' $\mathrm{a}$ ' (intercropped with ' $\mathrm{b}$ ')

$\mathrm{Z}_{\mathrm{ba}}=$ Sown proportion of species ' $b$ ' (intercropped with ' $a$ ')

LER was calculated using the below stated equation:

$$
\text { LER }=\frac{Y_{a b}}{Y_{a a}}+\frac{Y_{b a}}{Y_{b b}}
$$

RCC was calculated from the following equation:

$$
\mathrm{K}_{\mathrm{ab}}=\frac{\mathrm{Y}_{\mathrm{ab}}}{\mathrm{Y}_{\mathrm{aa}}-\mathrm{Y}_{\mathrm{ab}}} \times \frac{\mathrm{Z}_{\mathrm{ba}}}{\mathrm{Z}_{\mathrm{ab}}}
$$

Where, $K_{a b}=$ Co-efficient of species ' $a$ ' in presence of species ' $a$ '

$$
K_{b a}=\frac{Y_{b a}}{Y_{b b}-Y_{b a}} \times \frac{Z_{a b}}{Z_{b a}}
$$

Where, $\mathrm{K}_{\mathrm{ba}}=$ Co-efficient of species ' $\mathrm{b}$ ' in presence of species ' $\mathrm{a}$ ' and the yield advantage was decided from the product of the co-efficient i.e., $\mathrm{K}=\mathrm{K}_{\mathrm{ab}} \mathrm{x} \mathrm{K}_{\mathrm{ba}}$

And finally the economic analysis revealed the monetary advantage of the intercropping systems.

Statistical analyses of data were carried out by using MSTAT and critical differences at 5\% level of significance were calculated following Gomez and Gomez (1984).

\section{RESULTS AND DISCUSSION}

\section{Growth characteristics of maize and mungbean}

Among the growth attributing characters, plant height, dry matter accumulation, CGR (crop growth rate) and LAI (leaf area index) of both the crops were observed (Table $2 \& 3$ ). The different frequencies of irrigation influenced the plant height of both maize and mungbean particularly during the later stages showing positive response over the rainfed treatments. Plant height increased with increased levels of irrigation at 60 and 90 DAS (days after sowing) and harvest in maize whereas in case of mungbean 60 DAS and at harvest. Among the irrigation levels, irrigation at IW: CPE ratio of $0.75\left(\mathrm{I}_{3}\right)$ resulted in tallest plants in both the crops and 
shortest plants were observed in no irrigation without mulch. Alam et al. (1985) and Prasad et al. (1987) found increased plant growth due to frequent watering of field crops. However, plant height values in $\mathrm{I}_{3}$ were at par with $\mathrm{I}_{2}$ (irrigation at IW: CPE ratio of 0.50 ).

Among the inter cropping systems, maize and mungbean maintaining row ratio of 3:2 $\left(\mathrm{C}_{4}\right)$ recorded the maximum plant height followed by 1:1 row ratio $\left(\mathrm{C}_{3}\right)$ and sole maize $\left(\mathrm{C}_{1}\right)$. This might be due to the presence of mungbean in the intercropped situations that being leguminous in nature added to the nitrogen reserves of the soil. On the contrary, mungbean plants showed maximum plant height in sole crop $\left(\mathrm{C}_{2}\right)$ followed by $\mathrm{C}_{3}$ and $\mathrm{C}_{4}$ treatments where $\mathrm{C}_{2}$ treatment, comprises of mungbean faced no competition. Irrigation had favourable influence on LAI of both the crops and $\mathrm{I}_{3}$ (IW: CPE of 0.75) treatment maintained the greatest LAI value which increased with crop age and decreased at maturity (Table 2 and 3). Singh and Sridhar (1989) also reported similar results. Lowest LAI was recorded in rainfed and no mulch conditions. The highest LAI was shown by maize grown in 3:2 row ratio, while, sole mungbean gave maximum value at 60 DAS. CGR (crop growth rate) values of the crops showed similar trend as the leaf area indices value

\section{Yield attributes and yields of maize and mungbean}

Among the yield components, application of irrigation water at IW: CPE ratio of $0.75\left(\mathrm{I}_{3}\right)$ had favourable influence on LAI and dry matter accumulation resulting in greater number of cobs per plant in maize and pods per plant in mungbean (Table 4). These results were in conformity with those observed by Roy and Tripathi (1987). Length of the cob and number of grains per cob was recorded highest in $\mathrm{I}_{3}$ treatment. Bajwa et al. (1987) also reported the same trend. However, no significant variations were observed in the test weight values of both the crops due to treatment effects, which might be the genetical characteristics of plants, although highest value was with $\mathrm{I}_{3}$ irrigation level (Table 4).

Irrigation improved the grain and seed yield of maize and mungbean, respectively due to improvement in their yield attributing characteristics. The highest grain yield was recorded in case of $\mathrm{I}_{3}$ irrigation level because irrigation was given at critical physiological stages of both the crops. Similar results were reported by Trivedi et al. (1994). However in mungbean yield difference between $I_{3}$ and $I_{2}$ treatments were negligible.

With respect to the intercropping systems, treatments $\mathrm{C}_{4}$ (3:2 row ratio) in case of maize and sole mungbean $\left(\mathrm{C}_{2}\right)$ significantly had higher values of yield components and thereby increased yield. Between the two intercropping systems, 3:2 yielded higher than of 1:1 row ratio because maize was more dominating crop than that mungbean. The values of maize yield as affected by intercropping system were similar to that stated by Shahbazi et al. (2012). 


\section{Consumptive use (CU) of water and water use efficiency (WUE)}

There was a general trend that the CU of water in both the crops either sole or intercropped increased with increasing levels of irrigation and therefore, $\mathrm{I}_{3}$ treatment recorded the highest value of consumptive use of water (Table 5). Supply of higher levels of moisture in soil through irrigation resulted in increase in evapotranspiration losses which caused greater CU of water in both the crops. Similar observations were made by Singh et al. (2006) and Idnani et al. (2008) on mungbean. But in the present investigation, irrigation levels influenced the WUE of both the crops in respect to their crop yield. Among the sole systems, highest value of WUE recorded in $\mathrm{I}_{3}$ in case of maize and $\mathrm{I}_{2}$ in case of mungbean probably due to corresponding water use that produced moderate yield, resulted maximum effective utilization of water. Minimum WUE was recorded in treatment $\mathrm{I}_{0}$.

Inter cropping systems appreciably influenced consumptive use of water (CU) by the crops which was recorded the highest in case of sole maize $(252.49 \mathrm{~mm})$ and lowest in sole mungbean $(118.93 \mathrm{~mm})$ but showed nearly equal $\mathrm{CU}$ as intercrops (Table 5). Among the sole systems, highest WUE was with maize, while lower value obtained with sole mungbean. $\mathrm{CU}$ of water increased with the increasing levels of irrigation and the maximum WUE was observed with irrigation at IW: CPE ratio 0.75 under intercropping system of maize: mungbean in 3:2 row ratio followed by IW: CPE ratio 0.50. Among the sole crop systems, maximum WUE was with IW: CPE ratio 0.75 might be due to more consumption of water corresponding to production potential of maize, while, it was more under rainfed with mulch in case of mungbean. However, among the intercropping systems, the highest was in $\mathrm{I}_{3} \mathrm{C}_{4}$ treatment combination (17.75 kg ha $\mathrm{mm}^{-1}$ ) followed by $\mathrm{I}_{3} \mathrm{C}_{3}\left(15.27 \mathrm{~kg} \mathrm{ha}^{-1} \mathrm{~mm}^{-1}\right)$.

Aggressivity, Relative crowding coefficient (RCC) and Land equivalent ratio (LER)

The values of land equivalent ratios (LER) in table 6 depicts that both the intercropping systems gave highest value with irrigation at IW: CPE ratio of 0.75 and maize: mungbean at 3:2 gave more LER value than 1:1 combination. Besides, it decreased with decrease in frequency of irrigation. The treatment combination $\mathrm{I}_{3} \mathrm{C}_{4}$ gave $13 \%$ and $\mathrm{I}_{3} \mathrm{C}_{3}$ gave $8 \%$ yield advantage over the sole crop systems.

Since LER is perhaps the most appropriate measure for getting the total productivity on per unit area based on the yield of intercropping over mono-cropping at a given level of management. In this experiment maize grown in association with mungbean at 3:2 row ratio (I3C4) were found more profitable under adequate supply of irrigation water.

\section{CONCLUSION}

Results of the experiment showed that application of irrigation water and intercropping system remarkably influenced growth and yield of both the crops 
which resulted in maximum with irrigation applied at IW: CPE ratio 0.75 obtaining higher value of water use efficiency. Among intercropping systems, maize-mungbean maintained in 3:2 row ratio yielded better than that of others including sole system. Aggressivity study indicated that maize was the dominant species over mungbean and more advantageous in respect to other associated characters. Thus, maize grown in association with mungbean in 3:2 row ratio was found to be more profitable and advantageous due to more land sharing under intercropping system as well as application of irrigation at IW: CPE ratio of 0.75 in new alluvial zone of West Bengal.

\section{ACKNOWLEDGEMENT}

Authors are grateful to the University Research and Instructional Farm for providing land where the field experiment was carried out and also the laboratory facilities of the Department of Agronomy of the university where both chemical and physical analysis of the related samples were done well as for analysing the related samples.

\section{REFERENCES}

AOAC. 1995. Official Methods of Analysis, $16^{\text {th }}$ edition. Association of Official Analytical Chemists, Washington, DC

Alam, A. N. M. M. U. 1985. Evapotranspiration and yield of corn as related to irrigation timing during silking. Dissertation Abstract International B (Science and Engineering), 6(6): 1749B-1750B

Bajwa, M. S., Akhtar, A., Hussain, M. R. and Rajan, M. B. 1987. Effect of irrigation frequencies and nitrogen rates on the yield and protein contents of maize. Pakistan Journal of Agricultural Research, 8(3): 325-329

Banik, P. and Sharma, R. C. 2009. Yield and resource utilization efficiency in babycorn legume - intercropping system in the Eastern Plateau of India. Journal of Sustainable Agriculture, 33(4): 379-395

Brown, A. J. and Warncke, D. 1988. In: Recommended chemical soil test procedures for the North Carolina Region, 499. (Dahnke, W.C. Ed.). North Dakota Agricultural Experimental Station Bulletin. pp. 15-16

Dastane, N. G. 1972. A practical manual for water use research in agriculture. 2nd edition. Poona, Navabharat Prakashan

Gomez, K. A. and Gomez, A. A. 1984. Statistical Procedures for Agricultural Research, second edition, John Wiley and Sons, New York

Idnani, L. K. and Gautam, H. K. 2008. Water economization in summer greengram (Vigna radiata var radiata) as influenced by irrigation regimes and configurations. The Indian Journal of Agricultural Sciences, 78(3): 214-219

Jackson, M. L. 1973. Soil Chemical Analysis. Asia Publishing House, New Delhi 
Mandal, B. K., Rajak, S., Mandal, B. B. and Nandy, S. K. 1990. Yield and economics as influenced by intercrops of maize (Zea mays L.), groundnut (Arachis hypogaea L.) and greengram (Phaseolus radiatus L.). The Indian Journal of Agricultural Sciences, 60(3): 209-211

Olsen, S. R., Cole, C. V., Watanale, F. S. and Dean, L. A. 1954. Estimation of available phosphorus in phosphorus in soils by extraction with sodium bicarbonate. United States Department of Agriculture, Washington, DC

Piper, C. S. 1966. Mechanical Analysis. Soil and Plant Analysis (reprint for Asia). Hans Publishers, Mumbai, India. pp: 47-49

Prasad, U. K., Thakur, H. C., Pandey, R. D. and Sharma, N. N. 1987. Effect of irrigation and nitrogen on winter maize in calcareous saline alkali soil. Indian Journal Agronomy, 32(3): $217-220$

Roy, R. K. and Tripathi, R. S. 1987. Effect of irrigation and fertilizer on yield, water use efficiency and nutrient concentration in winter maize. Indian Journal Agronomy, 32(4): 314-318

Shahbazi, M. and Sarajuoghi, M. 2012. Evaluating Maize Yield in Intercropping with Mungbean. Annals of Biological Research, 3(3): 14-34

Singh, R.J., Idnani, L.K. and Rai, R.K. 2006. Grain yield, water use efficiency, economics and soil moisture extraction pattern of summer greengram (Vigna radiata L.) as influenced by planting and irrigation methods, irrigation schedules and VAM inoculation. Annals of Agricultural Research, 27(3): 306-310.

Sridhar, V. and Singh, R. A. 1989. Effect of irrigation levels on growth on rabi maize. Annals of Plant Physiology, 3(2): 212-221

Trivedi, S. J., Savalia, S. G., Ahlawat, R. P. S. and Patel, D. U. 1994. Effect of irrigation schedules, depth of ploughing and mulches on growth and yield of summer greengram. Legume Research, 17(2): 93-95

Walkley, A., Black, I. A. 1934. An examination of the deggaraff method for determining soil organic matter and a proposed modification of the chromic and titration method. Soil Science 37: 29-38 
Table 1. Physico-chemical properties of experimental soil (0-15 cm depth)

\begin{tabular}{|c|c|c|c|c|c|}
\hline Soil property & \multicolumn{2}{|c|}{ Value } & \multicolumn{3}{|c|}{ Method } \\
\hline Sand $(\%)$ & \multicolumn{2}{|c|}{40.2} & \multirow{3}{*}{\multicolumn{3}{|c|}{ International Pipette method (Piper, 1966) }} \\
\hline Silt $(\%)$ & \multicolumn{2}{|c|}{37.5} & & & \\
\hline Clay $(\%)$ & \multicolumn{2}{|c|}{22.3} & & & \\
\hline Textural class & \multicolumn{2}{|c|}{ Sandy Loam } & & & \\
\hline $\mathrm{pH}$ & \multicolumn{2}{|c|}{6.45} & \multicolumn{3}{|c|}{ Blackman's pH meter (Jackson, 1973) } \\
\hline Organic carbon $(\%)$ & \multicolumn{2}{|c|}{0.63} & \multicolumn{3}{|c|}{ Walkley and Black method, 1934} \\
\hline Total $\mathrm{N}$ content $(\%)$ & \multicolumn{2}{|c|}{0.059} & \multicolumn{3}{|c|}{ Micro-Kjeldahl's method (AOAC, 1995) } \\
\hline Available $\mathrm{P}\left(\mathrm{kg} \mathrm{ha}^{-1}\right)$ & \multicolumn{2}{|c|}{8.71} & \multicolumn{3}{|c|}{ Olsen's method, 1954} \\
\hline Available $\mathrm{K}\left(\mathrm{kg} \mathrm{ha}^{-1}\right)$ & \multicolumn{2}{|c|}{104.9} & \multicolumn{3}{|c|}{ Brown and Wamcke method, 1988} \\
\hline \multirow[t]{2}{*}{ Bulk density $\left(\mathrm{g} \mathrm{cc}^{-1}\right)$} & $0-15$ & $15-30$ & $30-45$ & $45-60$ & \multirow{2}{*}{$\begin{array}{l}\text { Field method using } \\
\text { core sampler (Dastane, } \\
\text { 1972) }\end{array}$} \\
\hline & 1.45 & 1.47 & 1.49 & 1.52 & \\
\hline
\end{tabular}


SAARC J. Agri., 13(2): 94-107 (2015)

Table 2. Growth characteristics of maize as influenced by irrigation and intercropping system (data pooled over 2 years)

\begin{tabular}{|c|c|c|c|c|c|c|c|c|c|c|c|}
\hline \multirow[t]{2}{*}{ Treatments } & \multicolumn{4}{|c|}{ Plant height $(\mathrm{cm})$} & \multicolumn{4}{|c|}{ Leaf Area Index (LAI) } & \multicolumn{3}{|c|}{$\begin{array}{l}\text { Crop Growth Rate (CGR) } \\
\qquad\left(\mathrm{g} \mathrm{m}^{-2} \text { day }^{-1}\right)\end{array}$} \\
\hline & $\begin{array}{c}30 \\
\text { DAS }\end{array}$ & 60 DAS & 90 DAS & Harvest & $\begin{array}{c}30 \\
\text { DAS }\end{array}$ & $\begin{array}{c}60 \\
\text { DAS }\end{array}$ & $\begin{array}{c}90 \\
\text { DAS }\end{array}$ & Harvest & $\begin{array}{c}30-60 \\
\text { DAS }\end{array}$ & $\begin{array}{c}60-90 \\
\text { DAS }\end{array}$ & $\begin{array}{c}90 \text { DAS - } \\
\text { harvest }\end{array}$ \\
\hline \multicolumn{12}{|c|}{ Level of Irrigation (I) } \\
\hline $\mathrm{I}_{1}$ & 62.67 & 143.50 & 195.91 & 199.77 & 1.06 & 2.02 & 2.76 & 2.52 & 9.01 & 14.65 & 10.92 \\
\hline $\mathrm{I}_{2}$ & 63.91 & 153.60 & 206.64 & 212.13 & 1.13 & 2.19 & 2.89 & 2.66 & 9.10 & 15.17 & 11.50 \\
\hline $\mathrm{I}_{3}$ & 64.26 & 154.75 & 213.87 & 224.16 & 1.20 & 2.34 & 3.21 & 2.86 & 9.19 & 17.25 & 12.74 \\
\hline $\operatorname{S.Em}( \pm)$ & 2.011 & 2.656 & 3.571 & 2.968 & 0.038 & 0.070 & 0.096 & 0.054 & 0.568 & 0.350 & 0.527 \\
\hline \multicolumn{12}{|c|}{ Cropping system (C) } \\
\hline $\mathrm{C}_{1}$ & 62.11 & 141.66 & 194.93 & 201.02 & 1.06 & 1.96 & 2.69 & 2.24 & 8.98 & 14.25 & 10.69 \\
\hline $\mathrm{C}_{3}$ & 63.15 & 146.52 & 200.42 & 206.91 & 1.11 & 2.10 & 2.83 & 2.50 & 9.07 & 15.17 & 11.14 \\
\hline $\mathrm{C}_{4}$ & 64.06 & 152.78 & 207.30 & 212.08 & 1.16 & 2.23 & 3.06 & 2.81 & 9.15 & 15.85 & 11.99 \\
\hline $\operatorname{S.Em~}( \pm)$ & 3.205 & 2.194 & 3.243 & 1.899 & 0.047 & 0.067 & 0.082 & 0.093 & 0.526 & 0.302 & 0.341 \\
\hline $\mathrm{CD}(0.05)$ & NS & 6.578 & 9.722 & 5.694 & NS & 0.201 & 0.247 & 0.280 & NS & 0.907 & 1.023 \\
\hline
\end{tabular}

$\mathrm{I}_{0}$ - rainfed without mulch; $\mathrm{I}_{1}$ - rainfed with mulch; $\mathrm{I}_{2}$ - irrigation at IW/CPE ratio of $0.5 ; \mathrm{I}_{3}$ - irrigation at IW/CPE ratio of 0.75 ;

$\mathrm{C}_{1}$ - sole maize; $\mathrm{C}_{3}$ - maize: mungbean (1:1); $\mathrm{C}_{4}$ - maize: mungbean (3:2); DAS - days after sowing 
Table 3. Growth characteristics of mungbean as influenced by irrigation and intercropping system (data pooled over 2 years)

\begin{tabular}{|c|c|c|c|c|c|c|c|c|c|}
\hline \multirow[t]{2}{*}{ Treatments } & \multicolumn{3}{|c|}{ Plant height $(\mathrm{cm})$} & \multicolumn{3}{|c|}{ Leaf Area Index (LAI) } & \multicolumn{3}{|c|}{$\begin{array}{l}\text { Crop Growth Rate (CGR) } \\
\qquad\left(\mathrm{g} \mathrm{m}^{-2} \mathrm{day}^{-1}\right) \\
\end{array}$} \\
\hline & $30 \mathrm{DAS}$ & $60 \mathrm{DAS}$ & Harvest & $30 \mathrm{DAS}$ & $60 \mathrm{DAS}$ & Harvest & $\begin{array}{l}01-30 \\
\text { DAS }\end{array}$ & $\begin{array}{l}30-60 \\
\text { DAS }\end{array}$ & $\begin{array}{c}60 \text { DAS- } \\
\text { harvest }\end{array}$ \\
\hline \multicolumn{10}{|c|}{ Levels of Irrigation (I) } \\
\hline $\mathrm{I}_{0}$ & 16.68 & 28.87 & 29.82 & 2.06 & 2.41 & 1.48 & 2.22 & 4.46 & 2.82 \\
\hline $\mathrm{I}_{1}$ & 17.49 & 32.18 & 33.12 & 2.15 & 2.55 & 1.95 & 2.27 & 4.48 & 2.95 \\
\hline $\mathrm{I}_{2}$ & 18.64 & 34.01 & 35.96 & 2.23 & 3.02 & 2.18 & 2.37 & 4.65 & 3.53 \\
\hline $\mathrm{I}_{3}$ & 19.36 & 35.04 & 36.12 & 2.35 & 3.08 & 2.58 & 2.54 & 4.96 & 3.77 \\
\hline $\operatorname{S.Em}( \pm)$ & 0.967 & 1.007 & 1.358 & 0.195 & 0.127 & 0.128 & 0.112 & 0.226 & 0.105 \\
\hline $\mathrm{CD}(0.05)$ & NS & 3.484 & 4.701 & NS & 0.440 & 0.442 & NS & 0.781 & 0.364 \\
\hline \multicolumn{10}{|c|}{ Cropping system (C) } \\
\hline $\mathrm{C}_{2}$ & 19.03 & 34.21 & 35.83 & 2.38 & 2.90 & 1.88 & 2.49 & 5.18 & 3.43 \\
\hline $\mathrm{C}_{3}$ & 18.12 & 32.44 & 33.56 & 2.16 & 2.77 & 1.76 & 2.32 & 4.73 & 3.24 \\
\hline $\mathrm{C}_{4}$ & 16.99 & 30.93 & 31.88 & 2.06 & 2.13 & 1.28 & 2.24 & 4.28 & 2.92 \\
\hline S.Em $( \pm)$ & 0.854 & 0.824 & 1.023 & 0.176 & 0.169 & 0.126 & 0.140 & 0.211 & 0.129 \\
\hline $\mathrm{CD}(0.05)$ & NS & 2.470 & 3.068 & NS & 0.505 & 0.378 & NS & 0.633 & 0.386 \\
\hline
\end{tabular}

$\mathrm{I}_{0}$ - rainfed without mulch; $\mathrm{I}_{1}$ - rainfed with mulch; $\mathrm{I}_{2}$ - irrigation at IW/CPE ratio of $0.5 ; \mathrm{I}_{3}$ - irrigation at IW/CPE ratio of 0.75 ;

$\mathrm{C}_{2}$ - sole mungbean, $\mathrm{C}_{3}$ - maize: mungbean (1:1); $\mathrm{C}_{4}$ - maize: mungbean (3:2); DAS - days after sowing 
Table 4. Yield attributing characters, yield of maize and mungbean as influenced by irrigation and intercropping system (data pooled over 2 years)

\begin{tabular}{|c|c|c|c|c|c|c|c|c|c|c|}
\hline \multirow[t]{2}{*}{ Treatments } & \multicolumn{5}{|c|}{ Maize } & \multicolumn{5}{|c|}{ Mungbean } \\
\hline & $\begin{array}{c}\text { No. of } \\
\text { cobs plant }\end{array}$ & $\begin{array}{c}\text { No. of } \\
\text { grains cob } \\
1\end{array}$ & $\begin{array}{c}\text { Test wt } \\
(\mathrm{g})\end{array}$ & $\begin{array}{l}\text { Length of } \\
\operatorname{cob}(\mathrm{cm})\end{array}$ & $\begin{array}{c}\text { Grain } \\
\text { yield } \\
\left(\mathrm{t} \mathrm{ha}^{-1}\right)\end{array}$ & $\begin{array}{l}\text { No. of pods } \\
\text { plant }^{-1}\end{array}$ & $\begin{array}{c}\text { No. of } \\
\text { seeds pod } \\
1\end{array}$ & Test wt (g) & $\begin{array}{l}\text { Pod length } \\
\quad(\mathrm{cm})\end{array}$ & $\begin{array}{c}\text { Seed } \\
\text { yield } \\
\left(\mathrm{t} \mathrm{ha}^{-1}\right)\end{array}$ \\
\hline \multicolumn{11}{|c|}{ Levels of Irrigation (I) } \\
\hline $\mathrm{I}_{0}$ & 0.65 & 218.93 & 235.93 & 16.54 & 1.437 & 15.65 & 5.12 & 22.09 & 5.29 & 0.294 \\
\hline $\mathrm{I}_{1}$ & 0.72 & 225.74 & 241.93 & 18.55 & 1.728 & 16.80 & 6.10 & 22.56 & 5.54 & 0.405 \\
\hline $\mathrm{I}_{2}$ & 0.99 & 243.53 & 244.14 & 18.58 & 3.015 & 18.09 & 7.75 & 22.67 & 5.88 & 0.582 \\
\hline $\mathrm{I}_{3}$ & 1.07 & 257.63 & 298.63 & 21.13 & 3.545 & 20.92 & 8.79 & 23.74 & 6.07 & 0.596 \\
\hline $\operatorname{S.Em}( \pm)$ & 0.047 & 5.222 & 3.148 & 0.762 & 0.153 & 1.026 & 0.458 & 0.996 & 0.072 & 0.035 \\
\hline C.D.(0.05) & 0.161 & 18.072 & NS & 2.637 & 0.531 & 3.549 & 1.584 & NS & 0.248 & 0.123 \\
\hline \multicolumn{11}{|c|}{ Cropping system (C) } \\
\hline $\mathrm{C}_{1}$ & 0.59 & 207.88 & 236.35 & 17.45 & 2.970 & - & - & - & - & - \\
\hline $\mathrm{C}_{2}$ & - & - & - & - & - & 19.56 & 7.68 & 23.11 & 5.91 & 0.804 \\
\hline $\mathrm{C}_{3}$ & 0.76 & 221.13 & 239.83 & 19.94 & 1.928 & 16.48 & 6.38 & 22.95 & 5.69 & 0.347 \\
\hline $\mathrm{C}_{4}$ & 1.23 & 250.37 & 244.31 & 18.72 & 2.396 & 15.55 & 6.21 & 21.80 & 5.48 & 0.257 \\
\hline $\operatorname{S.Em}( \pm)$ & 0.047 & 0.067 & 0.082 & 0.093 & 0.449 & 0.767 & 0.324 & 0.905 & 0.113 & 0.027 \\
\hline C.D.(0.05) & NS & 0.201 & NS & 0.280 & 0.148 & 2.300 & 0.970 & NS & 0.339 & 0.082 \\
\hline
\end{tabular}

$\mathrm{I}_{0}$ - rainfed without mulch; $\mathrm{I}_{1}$ - rainfed with mulch; $\mathrm{I}_{2}$ - irrigation at IW/CPE ratio of $0.5 ; \mathrm{I}_{3}$ - irrigation at IW/CPE ratio of 0.75 ;

$\mathrm{C}_{1}$ - sole maize, $\mathrm{C}_{2}$ - sole mungbean, $\mathrm{C}_{3}$ - maize: mungbean $(1: 1) ; \mathrm{C}_{4}$ - maize: mungbean $(3: 2)$ 
Table 5. Consumptive use $(\mathrm{mm})$ and water use efficiency $\left(\mathrm{kg} \mathrm{ha}^{-1} \mathrm{~mm}^{-1}\right)$ of maize and mungbean as influenced by irrigation and intercropping system (data pooled over 2 years)

\begin{tabular}{|c|c|c|c|c|c|c|c|c|}
\hline \multirow[t]{3}{*}{ Treatments } & \multicolumn{8}{|c|}{ Inter cropping systems } \\
\hline & \multicolumn{2}{|c|}{ Sole maize } & \multicolumn{2}{|c|}{ Sole mungbean } & \multicolumn{2}{|c|}{ Maize + mungbean $(1: 1)$} & \multicolumn{2}{|c|}{ Maize + mungbean $(3: 2)$} \\
\hline & $\mathrm{CU}$ & WUE & $\mathrm{CU}$ & WUE & $\mathrm{CU}$ & WUE & $\mathrm{CU}$ & WUE \\
\hline \multicolumn{9}{|c|}{ Levels of irrigation (I) } \\
\hline $\mathrm{I}_{0}$ & 128.55 & 11.18 & 120.80 & 2.41 & 118.96 & 10.34 & 121.98 & 11.07 \\
\hline $\mathrm{I}_{1}$ & 124.28 & 13.90 & 118.93 & 3.40 & 130.72 & 11.63 & 131.65 & 13.98 \\
\hline $\mathrm{I}_{2}$ & 238.61 & 12.64 & 219.42 & 2.65 & 214.91 & 12.00 & 217.22 & 14.49 \\
\hline $\mathrm{I}_{3}$ & 252.49 & 14.04 & 245.17 & 2.44 & 234.88 & 15.27 & 235.69 & 17.75 \\
\hline
\end{tabular}

$\mathrm{I}_{0}$ - rainfed without mulch; $\mathrm{I}_{1}$ - rainfed with mulch; $\mathrm{I}_{2}$ - irrigation at IW: CPE ratio of $0.5 ; \mathrm{I}_{3}$ - irrigation at IW: CPE ratio of 0.75 ;

$\mathrm{CU}$ - consumptive use of water; WUE - water use efficiency and $\mathrm{C}_{1}$ - sole maize, $\mathrm{C}_{2}$ - sole mungbean, $\mathrm{C}_{3}-$ maize : mungbean (1:1); $\mathrm{C}_{4}-$ maize : mungbean (3:2) 
Table 6. Competitive functions of maize and mungbean intercropping system as influenced by irrigation (data pooled over 2 years)

\begin{tabular}{|c|c|c|c|c|c|c|c|c|c|c|c|c|}
\hline \multirow[t]{2}{*}{ Treatments } & \multicolumn{12}{|c|}{ Intercropping systems } \\
\hline & \multicolumn{6}{|c|}{ Maize + Mungbean $(1: 1)$} & \multicolumn{6}{|c|}{ Maize + Mungbean $(3: 2)$} \\
\hline \multicolumn{13}{|c|}{ Levels of irrigation (I) } \\
\hline $\mathrm{I}_{0}$ & +0.31 & -0.31 & 1.05 & 1.56 & 0.82 & 1.27 & +0.40 & -0.40 & 1.09 & 1.85 & 0.77 & 1.42 \\
\hline $\mathrm{I}_{2}$ & +0.43 & -0.43 & 1.07 & 1.85 & 0.75 & 1.38 & +0.56 & -0.56 & 1.11 & 2.55 & 0.70 & 1.78 \\
\hline $\mathrm{I}_{3}$ & +0.51 & -0.51 & 1.08 & 2.07 & 0.71 & 1.46 & +0.64 & -0.64 & 1.13 & 3.14 & 0.64 & 2.00 \\
\hline
\end{tabular}

$\mathrm{I}_{0}$ - rainfed without mulch; $\mathrm{I}_{1}$ - rainfed with mulch; $\mathrm{I}_{2}$ - irrigation at IW/CPE ratio of $0.5 ; \mathrm{I}_{3}$ - irrigation at IW/CPE ratio of 0.75 ;

$\mathrm{A}_{\mathrm{MS}}$ - aggressivity of maize on mungbean; $\mathrm{A}_{\mathrm{SM}}$ - aggressivity of mungbean on maize; LER - land equivalent ratio; $\mathrm{K}_{\mathrm{MS}}$ - co-efficient of maize in presence of mungbean; $\mathrm{K}_{\mathrm{SM}}$ - co-efficient of mungbean in presence of maize. 